\title{
Speaker-oriented syntax and root clause complementizers
}

\section{Cruschina, Silvio}

2018

Cruschina, S \& Remberger, E-M 2018 , ' Speaker-oriented syntax and root clause pÿcomplementizers ' , Linguistic variation , vol. 18 , no. 2 , pp. 336358 . https://doi.org/10.1075/lv.18.2

http://hdl.handle.net/10138/300010

https://doi.org/10.1075/lv.18.2

unspecified

acceptedVersion

Downloaded from Helda, University of Helsinki institutional repository.

This is an electronic reprint of the original article.

This reprint may differ from the original in pagination and typographic detail.

Please cite the original version. 


\title{
Speaker-oriented syntax and root clause complementizers
}

\author{
Silvio Cruschina \& Eva-Maria Remberger \\ (University of Vienna)
}

\begin{abstract}
The object of study of this paper is a Romance construction characterized by the presence of the complementizer in root clauses and by an evidential or epistemic meaning (i.e. $C$ constructions). In these structures, the complementizer is preceded by a functional element that morphologically coincides with an adjective or an adverb. From a morphosyntactic viewpoint, we show that these structures are monoclausal and that the epistemic or evidential item preceding the complementizer has undergone a process of grammaticalization becoming a functional element. As for their use and interpretation, we describe their primary semantic meaning, as well as their pragmatic extensions and functions which involve subjectification and intersubjectivity. We finally propose a syntactic configuration that can account for $\mathrm{C}$ constructions and their properties in the syntax representation. This configuration involves the assumption of a projection - in fact, a set of projections - above ForceP which encode speakeroriented and pragmatic features (e.g. evaluative, evidential, epistemic values).
\end{abstract}

KEYWORDS: evidential, epistemic, complementizer, speech act phrase, sentience domain, emphasis, Romance, left periphery, adverbs, subjectification, intersubjectivity

\section{Introduction}

In this paper we examine the morphosyntactic and interpretive properties of a Romance construction characterized by the presence of the complementizer in root clauses and by an epistemic meaning. In these structures, which we call Complementizer Constructions (henceforth $C$-constructions), the complementizer is preceded by a functional element that morphologically coincides with an adjective $(1,3)$ or an adverb (2), as shown in the following examples: ${ }^{1}$
a. Certo che ha capito! (It.) certain that have.3SG understand.PST.PTCP
b. ¡Claroque entendió! (Sp.) clear that understand.PST.3SG 
'Of course s/he understood!'

(2)

a. ¡Evidentemente que va a ser declarado culpable! (Sp.) evidently that go.3SG to be.INF declare.PST.PTCP guilty

'Of course, he will be found guilty!'

(Gutiérrez-Rexach 2001:194)

c. Bineînţeles că vine. (Ro.)

of.course that come.3SG

'Of course s/he's coming.'

(Hill 2007, 2012:282)

(3) a. Capace che sono già partiti. (It.)

possible that be.3pl already leave.PST.PTCP

'It's possible/likely that they have already left.'

(Cruschina 2015:3)

b. Capaz que ves un día a tu mujer del brazo con possible that see.2SG one day ACC your wife of.the arm with otro $y$ te pones furioso. (Sp.)

another and you=put.2sG furious

'One day you might see your wife go arm in arm with somebody else and you'll get furious!' [CORDE. 1955. Benedetti, Mario. Ida y vuelta. Uruguay]

The adjectives or adverbs in the C-constructions in (1) and (2) have a subjective or speakeroriented function: some elements clearly have an epistemic meaning corresponding to English certainly, of course; others are traditionally described as evidential adverbs or adjectives (e.g. clear(ly), evident(ly), obvious(ly)). In fact, what they all do is to highlight the speaker's degree of certainty towards the truth of the proposition denoted by the utterance on the basis of personal evidence or knowledge. The problem of the divide between epistemicity and evidentiality is a general long-standing issue, which becomes evident also with respect to Cconstructions. Subjective epistemicity interacts - and, according to some scholars, overlaps with evidentiality, in particular with inferential evidentiality (cf. van der Auwera \& Plungian 1998:86, Dendale et al. 2001:242, Plungian 2001:354; see Cornillie 2009 for a differentiation 
of these two categories). For this reason, the C-construction has been characterized as either epistemic (Cruschina \& Remberger 2017, Kocher 2017) or evidential (cf. Hill 2007, 2012).

As will be discussed in Section 3, we will capture the distinct meanings that characterize the $\mathrm{C}$-constructions in terms of subjective and objective epistemicity, even when the adjective or adverbs featuring the C-construction would otherwise express an evidential value in its normal use. ${ }^{2}$ Therefore, while the semantic import of the examples in (1) and (2) will be analysed in terms of subjective epistemicity, we will argue that the C-constructions in (3) featuring Italian capace che and Spanish capaz que have an objective epistemic connotation, indicating that the speaker possesses enough knowledge to safely claim that there is an actual chance that the proposition is true. In this case, the meaning of the $\mathrm{C}$-construction corresponds to the English expressions 'it is possible that', 'it is likely that'. ${ }^{3}$

C-constructions are found in most Romance languages (cf. Hill 2007, 2012, RodríguezEspiñeira 2014, Suñer \& Di Tullio 2014, Cruschina 2015, López-Couso \& Méndez-Naya 2015, Cruschina \& Remberger 2017) and are also possible in a delimited register of English (cf. Radford 2013). ${ }^{4}$ In this paper, we will concentrate on examples from Romance, in particular Italian, Spanish and Romanian, and will examine the morphosyntactic properties and the interpretive contribution of their three main components: the functional epistemic or evidential element, the complementizer, and the clause following it. Section 2 provides evidence in favour of the hypothesis that $\mathrm{C}$-constructions are monoclausal and that we are thus dealing with cases of root complementation. In section 3, the precise interpretation of the functional elements that can enter the C-constructions will be discussed, while in Section 4 a syntactic implementation that can account for the main properties of $\mathrm{C}$-constructions will be proposed, with a special attention to the emphatic use of these constructions. The main findings and assumptions of the paper will be summarized in Section 5, together with some final closing remarks.

\section{Monoclausality and root complementation}

One may argue that the most straightforward analysis of C-constructions is in terms of copula omission. According to this analysis, C-constructions are biclausal structures in which the copula of an impersonal expression such as 'it is certain', 'it is possible', etc., has been elided. The corresponding structure of the Italian example (1a) is illustrated in (4), where the copula $\grave{e}$ (be.PRS.3SG) is omitted: 
The (embedded) subject clause following the impersonal expression is thus selected by the adjectival predicate of the main clause. Under closer scrutiny, however, it becomes clear that the copula omission analysis runs into a series of problems and cannot be maintained. We claim that biclausal structures like that in (4) are at the origins of C-constructions, but a subsequent process of grammaticalization took place and C-constructions are now, i.e. synchronically, to be analysed as monoclausal structures (see also Hill 2007, 2010, 2012, Kocher 2014, 2017, Cruschina 2015, Cruschina \& Remberger 2017).

\subsection{Against the copula-omission analysis}

The first piece of evidence in favour of the monoclausal hypothesis and against an analysis based on copula ellipsis comes from C-constructions whose first element is an adverb. The examples in (2), for instance, are hardly compatible with the copula omission analysis since they involve adverbs (evidentemente, bineinţeles) which cannot be part of a copular impersonal expression and cannot select for a subject clause:
a. (*iEs/está) evidentemente que va a ser declarado culpable! (Sp.) be./stay.3SG evidently that go.3SG to be.INF declared guilty
b. $\left({ }^{*} E\right)$ bineînţeles că vine. (Ro.)
be.3SG of.course that come.3SG

When it corresponds to an adjective, moreover, the epistemic element of a C-construction cannot be modified, unlike when it occurs in a biclausal structure. Observe the contrast between (6a) and (7a), on the one hand, which contain an overt copula, and (6b) and (7b) on the other, where no copula is present. Modification is also impossible if the element introducing the Cconstruction is an adverb, as in the Spanish example in (8):
(6) a. È del tutto / assolutamente /quasi certo che domani andiamo al mare! (It.) is of.the all/ absolutely /almost certain that tomorrow go.1PL to.the sea
b. *Del tutto/*assolutamente/*quasi certo che domani andiamo al mare! (It.) of.the all / absolutely / almost certain that tomorrow go.1PL to.the sea


'It is completely/absolutely/nearly certain that we will go to the sea tomorrow!'

(7) a. Está muy claro que la situación es complicada. (Sp.)

stay.3SG very clear that the situation be.3SG complex

'It's clear that the situation is complex.'

b. ¡(*Muy) claro que la situación es complicada! (Sp.)

very clear that the situation is complex

(8) (*Muy) evidentemente que va a ser declarado culpable! (Sp.)

be./stay.3SG evidently that go.3SG to be.INF declared guilty

We must also rule out the possibility that the adjective is the predicate of an implicit referential subject, rather than part of an impersonal expression (cf. 9a). If this were the case, we would expect gender and/or number inflection on the adjective to be possible once the copula is omitted (cf. 9b):
a. Sono certa/certi
che domani
andiamo al mare. (It.)
be.1SG/3PL certain.F.SG/certain.M.PL that tomorrow go.1PL to.the sea 'I'm sure/we are sure that we will go to the sea tomorrow.'
b. *Certa/certi che domani andiamo al mare. (It.) certain.F.SG/certain.M.PL that tomorrow go.1PL to.the sea

It must be clear that we are not indiscriminately excluding that copula omission could apply to biclausal structures of the type exemplified in (4). This is probably the most intuitive analysis when modification applies. In the Italian La Repubblica corpus, for example, we found a few instances of quasi certo che ('almost certain that') with no copula. The frequency of such cases, however, is relatively scarce if we consider that there are only 10 occurrences out of 401 hits with certo che with no overt copula feature modification. Similarly, for Spanish we found a few examples with casi seguro que ('almost sure that') in CREA (Corpus de referencia del español actual). Most importantly, all these occurrences have neither the subjective epistemic or evidential meaning typical of the construction under examination (cf. §3); rather, the CP is clearly the subject of the adjectival predication (cf. Cruschina \& Remberger 2017:91, fn. 11). 
We have also observed that most of the examples discussed in the literature and found in the relevant corpora involve indicative clauses, which may be taken as evidence for the lack of subordination or biclausality. ${ }^{5}$ To a certain extent, however, a subjunctive verbal form is possible (cf. NGLE 2009:3239, § 43.4j, Cruschina \& Remberger 2017:91), and the presence of the subjunctive mood presumably signals a syntactic dependency and, hence, the biclausal nature of the construction. As mentioned above, we do not categorically exclude that in a few cases copula elision applies, especially in conjunction with the subjunctive mood.

\subsection{Syntactic distribution and the position of the complementizer}

The strong restrictions on modification show that the first element of the C-construction does not exhibit the properties of an ordinary adjectival predicate, but it rather behaves like a functional element. This leads to the assumption that the $\mathrm{CP}$ is not selected by the adjective in a biclausal structure, but is rather modified by it in a monoclausal configuration. Further evidence supporting the idea that $\mathrm{C}$-constructions are monoclausal and involve a case of root complementation comes from its distribution. C-constructions can be embedded neither within a relative clause (10a) nor within a complement clause (10b), but can only occur as root clauses: 6
a. *La ragazza che chiaro che (la) invitiamo... (It.) the girl that clear that her= invite.1PL
b. *Ho sentito che chiaro che la invitiamo. (It.) have.1SG hear.PST.PTCP that clear that her= invite.1PL

In order to establish the exact position of the components of the C-construction, let us now look at the distribution and ordering restrictions with respect to other left peripheral elements. The strongest restriction concerns the adjacency between the epistemic element and the complementizer, whereby no constituent can intervene between them:
a. Certo (*mio fratello) che (mio fratello) ha capito! (It.) certain my brother that my brother have.3SG understood
b. ¡Claro (*mi hermano) que (mi hermano) entendió! (Sp.) clear my brother that my brother understand.PST.3SG 'Of course my brother understood!' 
Topics can precede the C-construction. However, only shifting or aboutness topics (ATop) (cf. $12 \mathrm{a}, 12 \mathrm{~b}, 13 \mathrm{a})$ are fully acceptable in this position, while other types of topic, especially those that receive a given or familiar reading (GTop) (cf. Frascarelli \& Hinterhölzl 2007), prove rather marginal (cf. 12c). The $\mathrm{CP}$ of the $\mathrm{C}$-construction seems to possess an active left periphery, with available topic and foci projections immediately after the complementizer (cf. Ion and la mare, respectively, in (13b)): ${ }^{7}$

a. Mio cugino, certo che lo invitiamo! (It.)

my cousin certain that him=invite.1PL

'My cousin, of course we'll invite him!'

b. Alla festa, certo che ci vado! (It.)

to.the party certain that there $=$ go. $1 \mathrm{SG}$

'Of course I'll go to the party!'

c. ?? Alla festa, certo che ci vado con Luca! (It.)

(GTop) to.the party certain that there= go.1SG with Luca

'Of course I'll go to the party with Luca!'

a. Ion, normal că nimeni nu-l mai vrea pe el. (Ro.) (ATop) Ion normal that nobody not-him= more want.3SG ACC him

'As for Ion, obviously nobody wants him anymore.'

b. Normal că Ion la mare se duce, nu la munte. (Ro.) (Comp-GTop-Foc) normal that Ion to sea $\mathrm{SE}=$ goes not to mountain 'Obviously, Ion goes to the sea, not in the mountains.'

(Hill 2012:284)

Aboutness topics are generally considered to occur very high in the syntactic structure, presumably higher than ForceP, while given topics are typically placed lower in the left periphery (cf. Frascarelli \& Hinterhölzl 2007, Bianchi \& Frascarelli 2010). The given interpretation of the sentence-initial topic in (12c) is forced by placing the focus on the final constituent con Luca: such narrow focalization is only possible if the initial topic is already active - and hence given - in the context, and cannot be used to (re-)introduce a new topic. Along the lines of Hill (2007), we therefore conclude that in C-constructions the 
complementizer occurs in Force ${ }^{\circ}$, and that the clause immediately following it is not just a TP because it displays active topic and focus projections within its left periphery (cf. 14):

$$
\text { [ATop [ForceP Comp [GTop [Foc [ [TP ... ] ] ] ] ] }
$$

The discussion above implies that the functional element represented by the adjective or adverb must occupy a position higher than ForceP, which it in fact modifies. Following Speas \& Tenny (2003) and Hill (2007), we claim that this position lies in the scope of the Speech Act Phrase (SAP), a projection above ForceP which (at least in the original proposal by Speas and Tenny 2003 ) includes a Point of View domain (POV, SentienceP, EvalP); this domain interacts with the SAP since it encodes speaker-oriented discourse and pragmatic features (e.g. evaluative, evidential, epistemic values). We thus propose the following syntactic representation for our C-constructions:

$$
\text { [ATop [SAP [SentienceP [ForceP Comp [GTop [Foc [TP ... ] ] ] ] ] ]] }
$$

Hill $(2007,2010)$ proposes that the epistemic/evidential element has a head status. It modifies the root clause (ForceP or CP), promoting the speaker's point of view (see also Giorgi 2010 for a similar idea). Recall that the functional element now displays properties of a grammaticalized element, in that it can be neither inflected nor modified (cf. §2.1): we interpret this categorial change as the result of a process of grammaticalization that transformed the former adverbial/adjectival element into a functional element that does not project anymore. ${ }^{8}$ In the next section, we turn to the interpretation of the C-construction and, in particular, to the speaker-oriented import of the functional element.

\section{The functional element preceding the complementizer}

In the introduction, we mentioned that two possible readings of the $\mathrm{C}$-construction are possible: the subjective and the objective epistemic reading. This distinction draws on work by Lyons (1977), Kratzer (1981), Nuyts (2001) and Traugott $(1989,1995)$ with respect to epistemic modality, as well as from Traugott (2010) for more general assumptions on subjectivity, subjectification and language change. Different closely-related terms have been used to characterize subjective meanings, e.g. speaker's commitment and qualification (Lyons 1977:797), expression of the speaker (Finegan 1995:1), speaker attitude or viewpoint (Traugott 2010:32). We adopt the term subjective epistemicity to define the subjective interpretation that 
arises in C-constructions and that is anchored to the speaker by means of the SAP. In the following sections the meaning of subjectivity will become clearer through a set of contrasts with structures encoding objective epistemicity. ${ }^{9}$

\title{
3.1 Subjective vs. objective readings
}

Recall from Section 1 that not all C-constructions have a subjective epistemic value. When adjectives or adverbs meaning 'possible' or 'likely' (cf. (3) above) appear in the Cconstruction, the most natural reading is the objective one. On the other hand, if other adjectives or adverbs are used, such as the equivalent of certain/of course, obvious(ly) or evident(ly), that is, elements encoding a higher degree of epistemic or evidential confidence, the $\mathrm{C}$-construction most typically receive a subjective interpretation. In what follows, we clarify the subjective vs. objective distinction with two types of contrast:

(a) a biclausal epistemic structure with an impersonal expression vs. the C-construction containing the same epistemic element and the same $\mathrm{CP}$, and

(b) a C-construction vs. the equivalent construction without a complementizer (cf. Cruschina \& Remberger 2017).

We illustrate the first contrast with an example from Italian (15), while the second one will be presented by commenting on a Romanian example (16) originally reported in Hill (2007).

\author{
(15) a. Era chiaro che erano disperati. (It.) \\ be.PST.3SG clear that be.PST.3PL desperate \\ 'They were clearly desperate (lit. it was clear that they were desperate).' \\ b. Chiaro che erano disperati! (It.) \\ clear that be.PST.3PL desperate \\ 'Clearly, they were desperate!'
}

In (15a) the CP che erano disperati 'that they were desperate' is the subject of the predicate era chiaro 'it was clear'; by uttering this sentence the speaker asserts that the predicate chiaro holds for the subject clause. The propositional content of the CP in (15b) is identical to that of (15a), but now the CP is directly anchored to the discourse, by means of the SAP which provides the speaker's coordinates, whereas chiaro encodes the speaker's assessment of its content. In (15a) the speaker's evaluation is presented as objectively asserted, based on the general knowledge of the facts or on the normal course of events (see Kratzer 1981). By 
contrast, in (15b) the proposition denoted by the $\mathrm{CP}$ is introduced as a subjective evaluation on the part of the speaker. This does not amount to saying that the situation described was clear to the speaker only, but rather that the C-construction emphasizes that this evaluation is based on the genuine belief and commitment of the speaker about the truth of the proposition in the given context situation. Note also that the speaker's assessment of the proposition is not temporally anchored to the reference or topic time, namely, to the time the speaker refers to by describing a situation, but it is necessarily bound to the speech time (by the speaker index), that is, to the moment of speech (cf. Reichenbach 1947, Klein 1997 for the notions of reference or topic time and speech time). In (15a), by contrast, the time relation between reference time and speech time can be altered by modifying the tense of the copula (e.g. era 'it was', setting the reference time before the speech time, or sarà 'it will be', setting the reference time to a situation after the speech time), because the predicate chiaro could hold for the subject clause also in the past or in the future.

The second contrast is exemplified by the following Romanian sentence pairs, from Hill (2007:61):

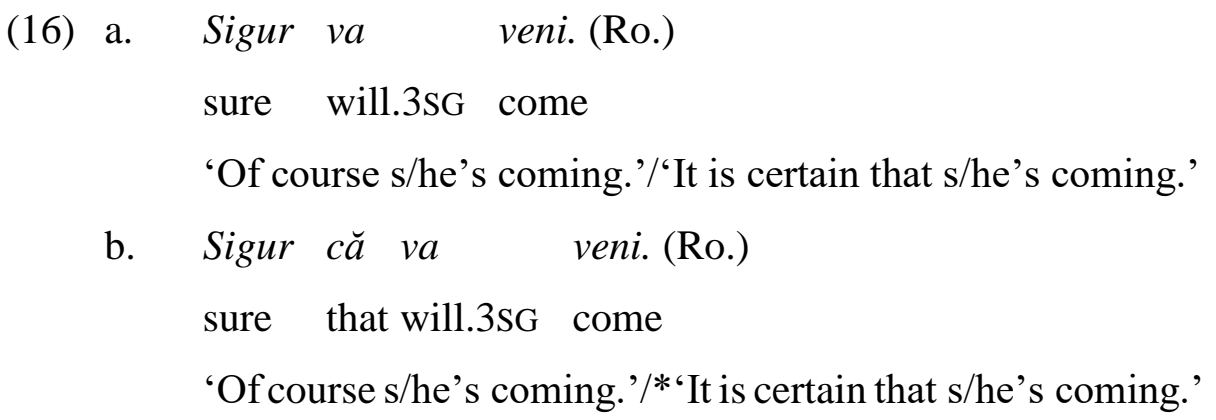

As is clear from the English translations, sentence (16a) is ambiguous between a subjective and an objective reading, while only a subjective interpretation (adverbial modification at the discourse level) is possible with (16b). ${ }^{10}$ The C-construction in (16b) emphasizes the speaker's attitude and belief, their epistemic certainty in this specific speech situation. This interpretation is also possible with (16a), especially if the epistemic adverb is prosodically focalized, but the normal interpretation of this sentence is the objective one (adverbial modification at the propositional level). Emphasis on the speaker's perspective implies that (16b) is only felicitous under specific contextual conditions, that is, whenever the truth of the associated proposition has been disputed or if the interlocutor casts doubts on its truth. Imagine the following scenario. John asks Mary if Paul will attend the conference next week. If Mary knows the answer and intends to express an objective certainty, she will reply with (16a). If Mary wants to emphasize 
her point of view, she will use (16b): perhaps she does not know for sure whether Paul will attend or not the conference, but she possesses enough information or cues to deduce or infer with certainty the truth of this proposition.

The contextual conditions that allow a felicitous use of C-constructions with a subjective reading must therefore include an important property: the proposition denoted by the $\mathrm{CP}$ must be anaphoric with respect to a salient antecedent, already or just introduced in the discourse. Moreover, the subjective interpretation is often associated with another function, which could perhaps be qualified in terms of intersubjectivity, whereby the C-construction additionally expresses attention to the hearer, bound to the hearer index in the SAP: by uttering (16b), for instance, the speaker (e.g. Mary in the scenario above) also intends to point out that both she and the hearer (John) have enough information, in the common ground as shared knowledge, to support certainty about the question under discussion. These two properties will be discussed in more detail in the next section.

\subsection{Beyond subjectivity: the interpretation of $C$-constructions with an anaphoric $C P$}

C-constructions may express a subjective or an objective speaker-oriented meaning. When they are associated with a subjective interpretation, providing speaker attitude and belief, different degrees of emphasis are possible, although emphasis is not a necessary condition. We analyse the imports deriving from emphasis on the speaker's point of view as secondary or pragmatic meanings (e.g. conversational implicatures). Accordingly, the C-construction may express: ${ }^{11}$

(17) a. Acknowledgment of the speaker's attitude towards the associated proposition, independently of the hearer's perspective;

b. Epistemic agreement with the hearer;

c. Indisputability of the speaker's evaluation towards the associated proposition, which should not be argued or put into question.

The acknowledgement meaning is not necessarily emphatic, while the other two (agreement and indisputability) are. The indisputability reading in $(17 \mathrm{c})$ may also be related to the speaker's intention to reach an evaluative alignment with the hearer, especially when the speaker recognizes or suspects that the hearer's beliefs do not match with their own. All these pragmatic extensions of the meanings that can be associated with $\mathrm{C}$-constructions require that the proposition at issue be already salient in the context (see also Kocher 2017). 
Consider the following Italian examples with respect to the proposition Gianni ha capito 'John (has) understood', introduced by speaker A:

(18) A: Tutti si chiedono se Gianni abbia capito o meno. (It.) all REFL $=$ ask.3PL if John have.SBJV.3SG understood or not 'Everybody wonders if John understood or not.'
B: Certo che ha
capito! (It.)
$(\rightarrow$ acknowledgement $)$
certain that have.3SG understand.PST.PTCP
'Of course he understood!'

(19) A: Credo che Gianni abbia capito. (It.)

believe.1SG that John have.SBJV.3SG understand.PST.PTCP

'I believe John understood.'

B: Certo che ha capito! $\quad(\rightarrow$ agreement, but also indisputability)

(20) A1: Non sono sicuro se Gianni abbia capito. (It.)

not be.1SG sure if John have.SBJV.3SG understand.PST.PTCP

'I am not sure if John understood.'
A2: Secondo me, Gianni non ha
capito. (It.)
according me John not have.3SG understand.PST.PTCP
'To me, John didn't understand.'
A3: Gianni ha capito? (It.)
John have.3SG understand.PST.PTCP
'Did John understand?'

B: Certo che ha capito!

$(\rightarrow$ indisputability)

In (18) speaker B simply expresses their opinion with respect to the question under discussion introduced by speaker A. By uttering the same C-construction in the context in (19), speaker B wants to emphasize their agreement with speaker A's epistemic statement. The same utterance would be felicitous also to challenge speaker A's possible doubts on the topic and to reassert the proposition with indisputable certainty. In the latter context, as well as in (20), the meaning of the C-constructions could be spelled out with expressions such as 'as you should know'. In 
this sense, C-constructions can also be used to perform the correction of a previous statement (cf. (20B) in response to (20A2). ${ }^{12}$

We therefore conclude that the presence of an adverb or an adjective in the SAP semantically expresses the attitude of the speaker with respect to a sentence whose propositional content is already salient and active in the discourse. The anaphoric status of the $\mathrm{CP}$ is a possibility with the non-emphatic readings, but it becomes a strict requirement in combination with the emphatic uses of the construction:

$$
\begin{array}{lllll}
\text { ¡Evidentemente que va a ser declarado } & \text { culpable! (Sp.) } \\
\text { evidently } & \text { that go.3SG to be.INF declare.PST.PTCP guilty }
\end{array}
$$

'Of course, he will be found guilty!'

(Gutiérrez-Rexach 2001:194)

In (21) the speaker asserts that it is evident that a verdict of guilty will be returned, but by using a C-construction the speaker also adds a "contextually determined emotive attitude towards this assertion", e.g. the emphatic meanings given in (17), which in turn imply doubts about the truth of the sentence, surprise or resentment because the addressee does not possibly share their view (cf. Gutiérrez-Rexach 2001:184, 2008, who calls this type of structures 'evidential exclamatives'). The anaphoric status of the $\mathrm{CP}$ imposes another difference between $\mathrm{C}$ constructions with the complementizer and the equivalent construction without a complementizer:

(22) a. \{Evidentemente/ciertamente/desde luego\}, Julia está muy enfadada. (Sp.) evidently certainly of course Julia is very angry

b. $\quad$ Evidentemente/ciertamente/desde luego\} que Julia está muy enfadada. (Sp.) evidently certainly of course that Julia is very angry (Hernanz 2007:165)

According to Etxepare (1997:98-99), whose examples are also discussed in Hernanz (2007:165), (22a) can be uttered out of the blue, but (22b) cannot because it is an emphatic sentence that can only be used to stress an already mentioned proposition (see also Etxepare 2008, 2010). 


\section{Discourse-oriented syntax and emphasis}

Drawing on a Split-CP model (Rizzi 1997), recent work has pursued the idea that the left periphery of the clause requires further expansion, so as to include a wider range of discourse properties (see, e.g., Speas \& Tenny 2003, Hill 2007, 2012, Haegeman \& Hill 2013, Wiltschko 2014). The present account shows that the morphosyntactic and interpretive properties of $\mathrm{C}$ constructions in fact require the assumption of a higher functional layer, above ForceP, whose features encode speaker's viewpoint and perspective. We assume that this higher functional layer corresponds to Speas \& Tenny's (2003) pragmatically relevant syntactic structure of the Speech Act Projection including a Sentience Domain: ${ }^{13}$

(23)

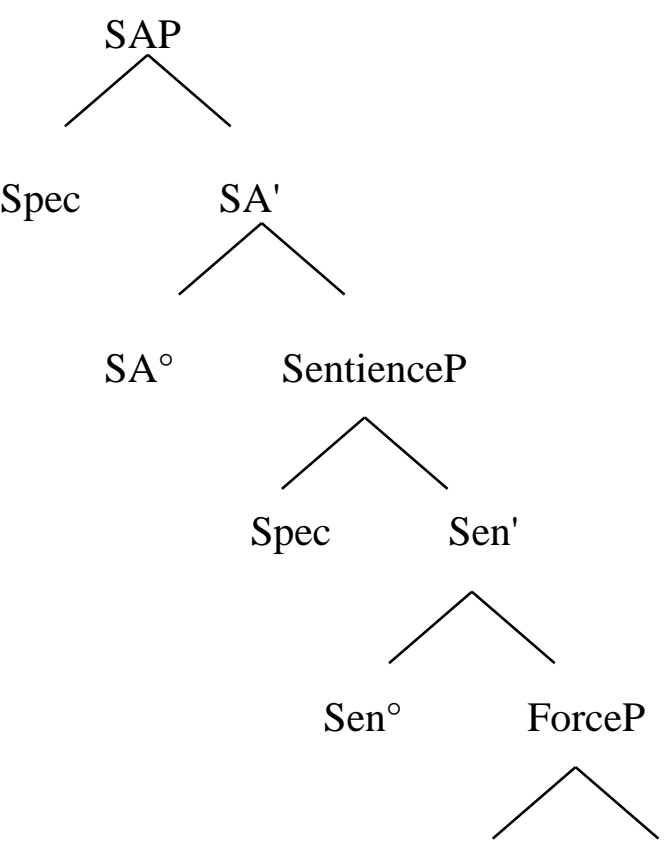

Force $^{\circ}$

This proposal reflects the position and the linear order of the elements in the C-construction as discussed in Section 2.2. It also captures the contrast between a C-construction and the equivalent construction without complementizer as exemplified in (16a) and (22a). As seen in the previous sections, the main properties of C-constructions are the following:

(i) GrammaticAlizATION: the functional element displays typical traits of grammaticalization, insofar as it cannot be inflected or modified;

(ii) COMP IN FORCE: syntactic distribution tests demonstrate that the complementizer occurs very high within the left periphery of the clause, presumably in the head of ForceP; ${ }^{14}$ 
(iii) SPEECH TIME: a temporally present interpretation of the speaker's evaluation or attitude, which refer to the speaker's deictic centre, even when the event they modify is located in a past temporal frame;

(iv) SubJeCtive MEANINGS: even though an objective interpretation is not excluded, depending on the specific functional element being used, C-constructions typically express a subjective meaning which highlights the speaker's point of view or attitude. The subjective meanings may be non-emphatic (acknowledgment) or emphatic (agreement or indisputability).

(v) DisCOURSE STATUS OF THE PROPOSITION: at least with the emphatic interpretation, the propositional content of the $\mathrm{C}$-construction must be anaphoric with respect to a salient antecedent.

The present analysis, based on the idea of a functional layer above the CP, can account for these properties. The epistemic functional elements are directly merged into the SentienceP and have then lost the typical properties of their original categories (adjectives or adverbs). The complementizer is merged as head of ForceP, above active given topic and focus projections within the left periphery which, as we saw, can be occupied by the relevant constituents (cf. (12) and (13)). Since they do not constitute independent predicates, but modifiers of root clauses, the speaker's point of view or attitude expressed by the functional element can only refer to the speech time, that is, to the speaker's deictic centre in the current context of speech. ${ }^{15}$ This is due to the interaction of the SentienceP with the SAP. We now turn to the last two properties of C-constructions, namely, the emphatic subjective meaning and discourse status of the $\mathrm{CP}$.

We have already discussed the difference between subjective and objective meanings (cf. $\S 3)$. However, as a special emphatic interpretation is often associated with subjective Cconstructions, the need for a syntactic distinction with respect to C-constructions with nonemphatic meanings becomes pressing. Recall also that the emphatic interpretation imposes a specific requirement on the discourse status of the $\mathrm{CP}$, i.e. it must be anaphoric to a salient antecedent. One possibility would be to analyse subjective C-constructions as a syntactic strategy to express verum focus or polarity emphasis (cf. Höhle 1992, Romero \& Han 2004, Breitbarth et al. 2013). We do believe that some type of focalization is at play in these constructions. However, what is in focus is not the sentence polarity or the verum, but rather, the speaker's modal evaluation (see Kocher 2017). A polarity particle can in fact appear before the C-constructions (24) or replace the propositional content as a TP anaphoric pronoun (25) (Krifka 2013): 
(24) a. iSí, claro que quiero ir con vosotros! (Sp.)

yes clear that want.1SG go.INF with you

'Of course I want to go with you!'

b. No, certo che non ritorno a casa da solo! (It.)

no certain that not return.1SG to home by alone

'No, of course I am not going back home by myself!'

(25) a. ¡Claro que sí! (Sp.)

clear that yes

'Of course!'

b. Certo che no! (It.)

certain that no

'Of course not!'

In both (24) and (25), despite the presence of an overt polarity particle, the emphasis is not on that particle, but on the epistemic element and therefore on the speaker's modal evaluation.

As already mentioned, with the emphatic interpretation, the $\mathrm{CP}$ must be strictly anaphoric to a salient antecedent, to the extent that no new material can be introduced. (cf. also Cruschina \& Remberger 2017 for examples adapted from Poletto \& Zanuttini 2013). There is thus a clearcut distinction between a focal and a given or presupposed part of the sentence. This could be captured by an implementation in terms of the FocP projection in the sense of Rizzi (1997). It must be noted, however, that FocP is typically the landing side of narrowly-focussed arguments and, depending on the language, some kinds of predicate which, from a semantic viewpoint, yield a set of alternative propositions (Rooth 1992). Crucially, emphatic C-constructions involve no set of alternatives. We would therefore like to suggest a different analysis. Emphasis in C-constructions corresponds to modal focalization, that is, focalization on the speaker's attitude towards the proposition, as well as on the relationship between the speech participants (see §3.2) encoded in the SAP and in the SentienceP above ForceP. This type of focalization is grammatically implemented by means of prosody, as it often happens with verum focus in many languages. It is also important to note that not all the evidential and epistemic adverbs that can enter C-constructions can be used emphatically: only those expressing a higher degree of epistemic or evidential confidence on the part of the speaker can occur in emphatic C- 
constructions (e.g. chiaro 'clear', certo 'certain', ovvio 'obvious' in Italian, claro 'clear', evidentemente 'evidently' in Spanish, and segur 'surely/certainly' in Romanian, but not capace 'possible' in Italian).

\section{Conclusions and final remarks}

In this paper we presented a first attempt to a systematic description of the morphosyntactic and interpretative properties of C-constructions in Romance, proposing corresponding syntactic configurations that may be able to account for their main properties. We started by showing that $\mathrm{C}$-constructions proper are monoclausal and, on the basis of the type of epistemic element that introduces the construction, we distinguished between subjective and objective Cconstructions. Subjective C-constructions are then to be subdivided into emphatic, derived from prosodic focalization of the epistemic or evidential element, and non-emphatic. As for the analysis, we propose a syntactic representation that exploits a functional domain above ForceP and which is able to capture the main properties shared by all subjective Cconstructions: prominence to speaker's point of view or attitude, apparent grammaticalization of the first element of the construction, and the role of the complementizer as a marker of the following proposition as discourse-given or corresponding to the question under discussion.

In our discussion, we only took adverbs and adjectives into consideration as the functional elements that can occur in the functional head above the complementizer in C-constructions. These two syntactic categories can be subsumed in the larger category of adverb or adverbial (see also Kocher 2017, but see González 2014, and Suñer \& Di Tullio 2014 for different analyses). This, however, does not imply that adverbs and adjectives exhaust all possibilities as for the lexical material that can be grammaticalized in these constructions. Other elements such as nouns and verbs can end up occupying the same position once they have undergone a similar process of grammaticalization (see Cruschina \& Remberger 2008, Cruschina 2015:15). The question nevertheless remains of whether analogous constructions featuring other elements are subject to the same syntactic and pragmatic constraints as the $\mathrm{C}$-constructions discussed here. Monoclausal evaluative verbal constructions in Spanish (e.g. anda que lo voy a hacer yo 'as if/no way am I going to do it', mira que eres pesado 'gosh aren't you annoying'; see Corr 2016) seem to show similar properties. ${ }^{16}$

A comparative and contrastive analysis of these constructions in light of the analysis developed and proposed in this study would indeed be interesting and important to understand the mechanisms of grammaticalization and the pragmatic factors that condition it. For the time 
being, however, we do not have enough evidence to propose a full parallelism between constructions headed by grammaticized nouns or verbs and, thus, to treat similar monoclausal constructions in the same lines as our C-constructions. In fact, for other originally verbal elements that have been reanalysed as adverbs and that occur in sentences that show different information structural properties from the C-constructions analysed here, like Sicilian dicica, we have proposed a different analysis (Cruschina \& Remberger 2008). Other root clause

phenomena in Italo-Romance involving $\mathrm{C}$ like the ones analysed in Munaro (in press) and Colasanti \& Silvresti (in press) seem instead more likely to be related to an exclamative illocutionary force. Further investigation into the differences and similarities across superficially and apparently alike root clause constructions is certainly needed.

\section{References}

Bianchi, Valentina \& Mara Frascarelli. 2010. Is topic a root phenomenon?. Iberia 2(1). 43.88. Bonami, Olivier \& Danielle Godard. 2007. Quelle syntaxe, incidemment, pour les adverbes incidents? Bulletin de la Société de Linguistique de Paris CII. 255-284.

Breitbath, Anne, Karen De Clercq \& Liliane Haegeman (eds.). 2013. Polarity emphasis: distribution and locus of licensing (Special Issue of Lingua 128).

Calaresu, Emilia. 2004. Testuali parole. La dimensione pragmatica e testuale del discorso riportato. Pavia: Franco Angeli.

Cinque, Guglielmo. 1999. Adverbs and functional heads. Oxford: Oxford University Press.

Colasanti, Valentina \& Giuseppina Silvestri. in press. Beyond force, mood, modality: matrix complementisers in Italo-Romance. In Silvio Cruschina, Adam Ledgeway \& Eva-Maria Remberger (eds.), Italian dialectology at the interface. Amsterdam: John Benjamins.

Cornillie, Bert. 2009. Evidentiality and epistemic modality: On the close relationship between two different categories. Functions of Language 16(1). 44-62.

Corr, Alice. 2016. Ibero-Romance and the Syntax of the Utterance. PhD thesis, University of Cambridge.

CREA - Real Academia española: Banco de datos (CREA) [online]. Corpus de referencia del español actual. http://www.rae.es (20 December 2014).

Cruschina, Silvio \& Eva-Maria Remberger. 2008. Hearsay and reported speech: Evidentiality in Romance. Rivista di Grammatica Generativa 33. 95-116.

Cruschina, Silvio \& Eva-Maria Remberger. 2017. Before the complementizer: Adverb types and root clause modification. In: Martin Hummel \& Salvador Valera (eds.), Adjectiveadverb interfaces in Romance, 81-109. Amsterdam: John Benjamins. 
Cruschina, Silvio. 2011. Tra dire e pensare: Casi di grammaticalizzazione in italiano e in siciliano. La Lingua Italiana: Storia, Strutture, Testi 7. 105-125.

Cruschina, Silvio. 2015. The expression of evidentiality and epistemicity: Cases of grammaticalization in Italian and Sicilian. Probus 27. 1-31.

Demonte, Violeta \& Olga Fernández Soriano. 2014. Evidentiality and illocutionary force. Spanish matrix que at the syntax-pragmatics interface. In Andreas Dufter \& Álvaro O. de Toledo (eds.), Left sentence peripheries in Spanish: Diachronic, variationist, and typological perspectives, 217-252. Amsterdam: John Benjamins.

Dendale, Patrick \& Tasmowski, Liliane. 2001. Introduction: Evidentiality and related notions. Journal of Pragmatics 33(3). 339-348.

Etxepare, Ricardo. 1997. The grammatical representation of speech events. $\mathrm{PhD}$ dissertation, Maryland.

Etxepare, Ricardo. 2008. On quotative constructions in Iberian Spanish. In Ritva Laury (ed.), Crosslinguistic studies of clause combining: The multifunctionality of conjunctions, 35-77. Amsterdam: John Benjamins.

Etxepare, Ricardo. 2010. From hearsay evidentiality to samesaying relations. Lingua 120. 604627.

Finegan, Edward. 1995. Subjectivity and subjectivisation: An introduction. In Dieter Stein and Susan Wright (eds.), Subjectivity and subjectivisation, 1-15. Cambridge: Cambridge University Press.

Frascarelli, Mara \& Roland Hinterhölzl. 2007. Types of topics in German and Italian. In Kerstin Schwabe \& Susanne Winkler (eds.), On information structure, meaning and form, 87-116. Amsterdam/Philadelphia: John Benjamins.

Garzonio Jacopo \& Poletto Cecilia. 2015. On polarity particles in Italian varieties. In Josef Bayer, Roland Hinterhölzl \& Andreas Trotzke (eds.), Discourse-oriented syntax, 211-228. Amsterdam: John Benjamins.

Giorgi, Alessandra. 2010. About the speaker. Towards a syntax of indexicality. Oxford: Oxford University Press.

González, Montserrat. 2014. Evidentiality, intersubjectivity and salience in Spanish and Catalan markers claro/clar and la verdad/veritat. Intercultural Pragmatics 11(3). 409-434. Grevisse, Maurice \& André Goosse. 2008. Le bon usage (14th ed.). Brussels: De Boeck \& Larcier.

Gutiérrez-Rexach, Javier. 2001. Spanish exclamatives and the semantics of the left periphery. In Johan Rooryck, Yves de Hulst \& Jan Schroten (eds.), Romance languages and linguistic 
theory 1999: Selected papers from 'Going Romance' 99 (Current Issues in Linguistic Theory 221), 167-194. Amsterdam: John Benjamins.

Gutiérrez-Rexach, Javier. 2008. Spanish root exclamatives at the syntax/semantics Interface. Catalan Journal of Linguistics 7. 117-133.

Haegeman, Liliane \& Virginia Hill. 2013. The syntacticization of discourse. In Raffaella Folli, Christina Sevdali \& Robert Truswell (eds.), Syntax and its Limits, 370-390. Oxford: Oxford University Press.

Hernanz, Maria Lluïsa. 2007. From polarity to modality: Some (a)symmetries between bien and si in Spanish. In Luis Eguren \& Olga Fernández Soriano (eds.), Coreference, modality, and focus: Studies on the syntax-semantics interface, 133-169. Amsterdam: Benjamins.

Hill, Virginia. 2007. Romanian adverbs and the pragmatic field. The Linguistic Review 24. 6186.

Hill, Virginia. 2010. Main clause că 'that' in Romanian. Bucharest Working Papers in Linguistics 12(2). 5-16.

Hill, Virginia. 2012. A main clause complementizer. In Lobke. Aelbrecht, Liliane Haegeman \& Rachel Nye (eds.), Main clause phenomena: New horizons, 279-296. Amsterdam: John Benjamins.

Hinterhölzl, Roland \& Nicola Munaro. 2015. On the interpretation of modal particles in nonassertive speech acts in German and Bellunese. In Josef Bayer, Roland Hinterhölzl \& Andreas Trotzke (eds.), Discourse-oriented syntax, 41-70. Amsterdam/Philadelphia: John Benjamins.

Höhle, Tilman. 1992. Über Verum-Fokus im Deutschen. Linguistische Berichte Sonderheft 4. 112-141.

Klein, Wolfgang. 1994. Time in language. London/New York: Routledge.

Kocher, Anna. 2014. Claro que son adverbios: Análisis de un proceso de gramaticalización. MA thesis, University of Vienna.

Kocher, Anna. 2017. From verum to epistemic modality and evidentiality: On the emergence of the Spanish Adv+C construction. Journal of Historical Linguistics 7(1/2). 77-110.

Kratzer, Angelika. 1981. The notional category of modality. Hans J. Eikmeyer \& Hannes Rieser, (eds.), Worlds, words, and contexts, 38-74. De Gruyter, Berlin.

Krifka, Manfred. 2013. Response particles as propositional anaphors. Proceedings of SALT 23. $1-18$.

La Repubblica - Corpus. http://sslmit.unibo.it/repubblica (31 January 2015). 
López-Couso, María José \& Belén Méndez-Naya. 2015. Epistemic/evidential markers of the type verb + complementizer. Some parallels from English and Romance. In Andrew D. M. Smith, Graeme Trousdale \& Richard Waltereit (eds.), New directions in grammaticalization research, 93-120. Amsterdam: John Benjamins.

Lorenzetti, Luca. 2002. Sulla grammaticalizzazione di dice nell'italiano parlato. In Sabine Heinemann, Gerald Bernhard \& Dieter Kattenbusch (eds.), Roma et Romania. Festschrift für Gerhard Ernst zum 65. Geburtstag, 211-221. Tübingen: Niemeyer.

Lyons, John. 1977. Semantics. Cambridge: Cambridge University Press.

Michaelis, Laura. 2001. Exclamative constructions. In Martin Haspelmath, Ekkehard König, Wulf Oesterreicher \& Wolfgang Raible (eds.), Language typology and language universals, 1038-1050. Berlin: De Gruyter.

Molinier, Christian \& Françoise Levrier. 2000. Grammaire des adverbs. Geneva: Droz.

Munaro, Nicola. in press. On the syntactic encoding of lexical interjections in Italo-Romance. In Silvio Cruschina, Adam Ledgeway \& Eva-Maria Remberger (eds.), Italian Dialectology at the Interface. Amsterdam: John Benjamins.

NGLE - Real Academia Española. 2009. Nueva gramática de la lengua española, 2 Vols. Madrid: Espasa-Calpe.

Nuyts, Jan. 2001. Subjectivity as an evidential dimension in epistemic modal expressions. Journal of Pragmatics 33(3). 383-400.

Plungian, Vladimir Aleksandrovič. 2001. The place of evidentiality within the universal grammatical space. Studies in Language 12(1). 349-357.

Poletto, Cecilia \& Raffaella Zanuttini. 2013. Emphasis as reduplication: Evidence from sì che/no che sentences. Lingua 128. 124-141.

Radford, Andrew. 2013. The complementiser system in spoken English: Evidence from broadcast media. In María Victoria Camacho Taboada, Ángel Jiménez-Fernández, Javier Martín-González \& Mariano Reyes-Tejedor (eds.), Information structure and agreement, 11-54. Amsterdam/Philadelphia: John Benjamins.

Reichenbach, Hans. 1947. Elements of symbolic logic. New York: MacMillan.

Rett, Jessica. 2011. Exclamatives, degrees, and speech acts. Linguistics and Philosophy 34. 411-442.

Rizzi, Luigi. 1997. The fine structure of the left periphery. In Liliane Haegeman (ed.), Elements of grammar, 281-337. Dordrecht: Kluwer.

Rodríguez-Espiñeira, María José. 2014. Emergencia e historia de la construcción es capaz que. In Maria Bargalló Escrivà, María del Pilar Garcés Gómez \& Cecilio Garriga Escribano 
(eds.), Llaneza. Estudios ofrecidos a Juan Gutiérrez Cuadrado, 205-218. A Coruña: Anexo de la Revista de Lexicografía.

Romero, Maribel \& Chung-hye Han. 2004. On negative yes/no questions. Linguistics and Philosophy 27(5). 609-658.

Rooth, Mats. 1992. A Theory of Focus Interpretation. Natural Language Semantics 1. 75-116.

Servidio, Emilio. 2014. Polarity particles in Italian: Focus, fragments, tags. Doctoral dissertation, University of Siena.

Simon-Vandenbergen, Anne-Marie \& Karin Aijmer. 2007. The semantic field of modal certainty: A corpus-based study of English adverbs. Berlin: Walter de Gruyter.

Speas, Peggy \& Carol L. Tenny. 2003. Configurational properties of point of view roles. In Anna Maria Di Sciullo (ed.), Asymmetry in grammar, 315-344. Amsterdam: John Benjamins.

Suñer, Avel·lina \& Àngela Di Tullio. 2014. Bare adjectives as syncretic forms. Borealis 3(1). 23-47.

Traugott, Elizabeth C.. 1989. On the rise of epistemic meanings in English: An example of subjectification in semantic change. Language 65. 31-55.

Traugott, Elizabeth C.. 1995. Subjectification in grammaticalization. In Dieter Stein and Susan Wright (eds.), Subjectivity and subjectivisation, 31-54. Cambridge: Cambridge University Press.

Traugott, Elizabeth C.. 2010. (Inter)subjectivity and (inter)subjectification: A reassessment. In Kristin Davidse, Lieven Vandelotte \& Hubert Cuyckens (eds.), Subjectification, intersubjectification and grammaticalization, 29-71. Berlin: de Gruyter.

van der Auwera, Johan \& Plungian, Vladimir Aleksandrovič. 1998. Modality’s semantic map. Linguistic Typology 2(1). 79-124.

Wiltschko, Martina. 2014. The Universal structure of categories. Towards a formal typology. Cambridge: Cambridge University Press.

Zanuttini, Raffaella \& Paul Portner. 2003. Exclamative clauses: at the syntax-semantics interface. Language 79(3). 39-81.

\section{NOTES}

\footnotetext{
${ }^{1}$ The evidence on which this study is based is taken from examples discussed in the literature or, when no source is indicated, was elicited from a number of native informants. As will be duly indicated, we have also consulted various corpora in order to retrieve natural examples and to check our findings against a wider empirical basis.

${ }^{2}$ This amounts to saying that the grammaticalization of an evidential adverb or adjective within the C-construction
gives rise to an overall epistemic reading of the construction, akin to the grammaticalization of an epistemic adverb
or adjective. In what follows, we will use the term evidential adverb or adjective to refer to the original value of
} 
the functional element preceding the complementizer in the C-construction, while maintaining that $\mathrm{C}$ constructions can only express epistemic meanings.

${ }^{3}$ The subjective vs. objective distinction with respect to the epistemic modality builds on Lyons (1977) and Kratzer (1981). For a more precise definition of the notion of subjective epistemicity as used in this paper (which slightly diverges from the previous literature), see Section 3 (see also Traugott 1995 and Nuyts 2001).

${ }^{4}$ The construction under investigation is also very common and frequent in French (see Molinier \& Lévrier 2000, Bonami \& Godard 2007, Grevisse \& Goosse 2008: $\$ 1121$ b):

(i) a. Certainement que Paul n' est pas venu.

certainly that Paul not be.3SG NEG come.PST.PTCP

'Paul certainly didn't come.'

b. Probablement que ce n' est pas leur faute.

probably that it not be.3SG NEG their fault

'It probably isn't their fault.'

For such a construction, an analysis has been proposed, according to which the adverb constitutes the head of a verbless clause which takes a sentence as its argument (Bonami \& Godard 2007). We have not yet investigated whether the French construction is fully parallel to that found in Italian, Spanish, and Romanian, obeying the same syntactic and pragmatic restrictions. For the time being, therefore, we have not included in French in our discussion, leaving this comparative task to future research.

${ }^{5}$ Even though it may fail in the colloquial language, the subjunctive is prescriptively required - and indeed preferred by most speakers - in biclausal impersonal constructions such as that in (i), proving that the subjunctive verb belongs to a subordinate clause:

(i) $\grave{E}$ possibile/capace che sia già partito.

be.PRS.3SG possible possible that be.PRS.SBJV.3SG already left

'It has probably already left.'

By contrast, the C-constructions equivalent to (i), that is, without the copula, are barely compatible with the subjunctive (cf. the example in (3a)), confirming their monoclausal status. On the diatopic variation concerning the use of capace, see Cruschina (2015).

${ }^{6}$ Clauses embedded under verbs of saying are exceptional in this case, since they allow a shift of the deictic centre from the speaker to the subject of the verb of saying (e.g.in free indirect discourse), cf. (i) taken from the web where an embedded certo che appears:

(i) Invece poi non so perché gliel'ho raccontato e lui non ha né riso né fatto facce,

... e ha detto che certo che lo capiva. (It.)

and have.3SG say.PST.PCTP that sure that it= understand.IMPF.3SG

'Instead I don't know why I told him and he neither laughed nor did he make faces, and he said, that, of course, he understood.'

${ }^{7}$ Note that the acceptability of topics and, above all, foci after the complementizer (cf. 13b) depends on the overall interpretation of the $\mathrm{C}$-constructions. In particular, our informants barely accept such an order with emphatic Cconstructions (cf. § 3).

${ }^{8}$ As pointed out by an anonymous reviewer, the findings and observations discussed in this section are also compatible with a weaker version of the reanalysis hypothesis, according to which grammaticalization has simply led to a structural deficiency of the adverb or adjective, which now cannot project an extended structure able to host modifiers. Under this view, the items in question may have retained their categorial status and at the same time be able to perform their functional role within the C-construction. This alternative analysis has obvious advantages on the learnability side, insofar as children do not have to acquire homophonous elements with a distinct categorial status. A way to reconcile the two perspectives is to assume that the elements occurring in the C-constructions do keep the categorial feature, but in that specific position of the C-construction (i.e. as head of the SAP in the analysis proposed here) grammaticalization makes the corresponding categorial feature inert.

${ }^{9}$ It must be clear that, even if their meaning could be somehow defined as emphatic, we do not consider Cconstructions as exclamative sentences (pace Gutiérrez-Rexach 2001, 2008), at least not in the sense of Zanuttini \& Portner (2003). Suffice it to say, for instance, that unlike exclamatives (see Michaelis 2001, Zanuttini and Portner 2003, Rett 2011), C-constructions need not characterize the situation described as exceptional, noncanonical or surprising, nor do they need to involve a degree component. 
${ }^{10}$ We thank Ion Giurgea for his comments on these examples and for his help to identify the appropriate context distinctions. Note that the same contrast arises in Italian between the $\mathrm{C}$-construction, e.g. sicuro/certo che viene (sure/certain that he-comes) and the structure with the corresponding adverb used as a clause modifier with no complementizer, e.g. sicuramente viene (surely he-comes) or viene sicuramente (he-comes for sure).

${ }^{11}$ For a detailed analysis of the semantic and pragmatic meanings and functions of modal adverbs (in English), see Simon-Vandenbergen \& Aijmer (2007).

${ }^{12}$ Poletto \& Zanuttini (2013) examine emphatic answers with polarity particles followed by a complementizer in Italian which present main properties in common with our C-constructions. Our analysis is indeed inspired by their work, although we arrive at a different conclusion, namely, that C-constructions are not biclausal. See also Servidio (2014), and Garzonio \& Poletto (2015).

${ }^{13}$ Our use of the SAP and SentienceP is a shorthand for the more complex structure assumed in Speas \& Tenny (2003), in which the Sentience Phrase in turn comprises an evaluative, an evidential and an epistemic projection, and encodes judgements and evaluations on the truth-value of the proposition. Note also that this is just one possible implementation of the ideas developed in this paper. Other similar accounts make use of other left peripheral projections such as Mod(ifier)P, which was introduced by Rizzi (2004) as a landing site for preposed adverbs and which has been split into an evaluative, an evidential, and an epistemic projection by Giorgi (2010) (see also Hill 2007, 2010, 2012). See also Hinterhölzl \& Munaro (2015) for a cartographic implementation of the distinct semantic nuances reflected by the subjective and objective distinction. The relationship between these projections and Cinque's (1999) projections remains an issue that we do not address here (see Speas \& Tenny 2003 for discussion).

${ }^{14}$ According to Hill (2010), two Force projections are available within the extended CP that she postulates for similar constructions.

${ }^{15}$ In Spanish the complementizer alone can refer to a reported speech event (cf. i), while in a similar structure in Italian the complementizer is preceded by the verb of saying which has lost part of its original semantic meaning and its grammatical properties (cf. ii). These constructions have a reportative function encoding indirect evidence (in Italian) or reported speech (in Spanish):

(i) Sp. Oye, que el Barça ha ganado la Champions.

listen.IMP that the Barça have.3SG win.PST.PTCP the Champions 'Listen, (someone said that) Barça won the Champions.' (Etxepare 2008:36)

(ii) It. Dice che ieri notte c'è stata una rissa in piazza. say.3SG that yesterday night there=is been a fight in square

'Apparently, yesterday night there was a fight in the square.'

Interestingly, both structures have been related to the SAP above the CP (cf. Demonte \& Fernández-Soriano 2014 for Spanish, and Cruschina 2015 for Italian). Italian dice, in particular, shows the same type of decategorialization typical of the functional elements in C-constructions: it can be neither inflected nor modified (see Cruschina 2011, 2015 for details, as well as Lorenzetti 2002, Calaresu 2004:39-42). On the one hand, like with C-constructions, a speaker-oriented meaning is certainly involved in these structures, in that there is a direct reference to the source of information at the basis of the speaker's utterance or to the manner in which the individual has come to learn of an event and of its truth. On the other, even if it somehow corresponds to a reproduction of a former speech act, the content of the propositional CP in these evidential and reportative constructions is generally not given in the discourse, and no emphasis occurs.

See Cruschina \& Remberger (2008) for a further development of this reportative or quotative construction, as well as of some C-constructions, which is found in several Romance varieties and which involves the univerbation of the functional element (an adjective, a noun or a verbal form) with an integrated complementizer, yielding a higher sentential adverb, in the sense of Cinque (1999).

${ }^{16}$ We thank an anonymous reviewer for pointing this out to us. 